David M. Ansley MD, Jung-un Lee PhD MD, David V. Godin PhD, ${ }^{*}$ Maureen E. Garnett MSc, * A. Karim Qayumi PhD MD

\section{Propofol enhances red cell antioxidant capacity in swine and humans}

Purpose: To determine the effect of an anaesthetic with antioxidant potential, propofol, on red blood cell (RBC) antioxidant enzyme activities and RBC susceptibility to peroxidative challenge.

Methods: Propofol was administered by intravenous bolus $\left(2.5 \mathrm{mg} \cdot \mathrm{kg}^{-1}\right)$ and continuous infusion (36 and $72 \mathrm{ml} \cdot \mathrm{hr}^{-1}$ in nine swine; $216 \mathrm{ml} \cdot \mathrm{hr}^{-1}$ in two swine), to achieve serum concentrations between 5 and $30 \mu \mathrm{g}^{\prime} \mathrm{ml}^{-1}$ for two hours at each rate. Arterial blood sampling was at $0,10,30,60$, and 120 min for each rate of infusion, for measurement of plasma propofol concentration, activities of plasma and RBC superoxide dismutase, glutathione peroxidase, gluthathione reductase, RBC catalase, and RBC malondialdehyde (MDA) formation in response to ex vivo oxidative challenge with t-butyl hydrogen peroxide (tBHP; $.5 \mathrm{mM}$ ). Antioxidant mechanisms were determined by in vitro study of MDA formation, GSH depletion, and oxidation of haemoglobin to methaemoglobin in human erythrocytes exposed to propofol $0-75 \mu \mathrm{M}$. The antioxidant potential of propofol was compared with that of alpha-tocopherol utilising the reaction with 2,4,6-tripyridyl-s-triazine (TPTZ).

Results: Propofol had no effect on plasma or RBC antioxidant enzyme activities. It inhibited RBC MDA production over the range of $0-20 \mu \mathrm{g} \cdot \mathrm{ml}^{-1}\left(y=-18.683 x+85.431 ; R^{2}=0.8174\right)$. Effective propofol concentrations for $25 \%$ and $50 \%$ reductions in MDA levels were 7-12 and $12-20 \mu \mathrm{g} \cdot \mathrm{ml}^{-1}$, respectively. Propofol has a similar effect on human erythrocytes in vitro $\left(R^{2}=0.98\right)$.

Conclusion: Propofol antagonises the effects of forced peroxidation of red cells at anaesthetic and sub-anaesthetic concentrations in swine. Its actions include scavenging of oxygen derived free radicals in a tocopherol-like manner.

Objectif : Déterminer l'effet d'un agent anesthésique possédant un potentiel antioxydant, le propofol, sur l'activité d'un enzyme antioxydant des globules rouges (GR) et sur la susceptibilité des GR à une provocation peroxydative.

Méthodes : Le propofol a été administré en bolus intraveineux $\left(2,5 \mathrm{mg} \cdot \mathrm{kg}^{-1}\right.$ ) et en infusions continues (36 et 72 $\mathrm{ml} \cdot \mathrm{h}^{-1}$ chez 9 porcs; $216 \mathrm{ml} \cdot \mathrm{h}^{-1}$ chez 2 porcs) pour obtenir des concentrations sériques entre 5 et $30 \mu \mathrm{g} \cdot \mathrm{ml}^{-1}$ durant deux heures à chaque vitesse d'infusion. Des prélèvements sanguins par voie artérielle ont été réalisés à $0,10,30$, 60 et 120 min. pour chaque vitesse d'infusion; on a mesuré la concentration de propofol, l'activité de la superoxyde dismutase du plasma et des GR, de la peroxydase du glutathion, de la réductase du glutathion, de la catalase du GR, ainsi que de la formation dans le GR de la malondialdehyde (MDA) en réponse à une provocation oxydative ex vivo avec le peroxyde d'hydrogène t-butylique ( $t B H P, 1,5 \mathrm{mM})$. Les mécanismes antioxydants ont été déterminés par l'étude in vitro de la formation de MDA, de la déplétion de GSH ainsi que de l'oxydation de l'hémoglobine en methémoglobine dans des GR humains exposés au propofol 0-75 $\mu \mathrm{M}$. Le potentiel antioxydant du propofol a été comparé à celui de l'alpha-tocophérol en utilisant la réaction avec le 2,4,6-tripyridyl-s-triazine (TPTZ).

Résultats : Le propofol n'a pas eu d'effet sur l'activité de l'enzyme antioxydant du plasma ou des GR. II a inhibé la production de MDA par les GR pour tout le spectre de $0-20 \mu \mathrm{g}^{\prime} \mathrm{ml}^{-1}\left(y=-18.683 \mathrm{x}+85.431 ; \mathrm{R}^{2}=0,8174\right)$. Les concentrations de propofol efficaces pour obtenir une réduction des taux de MDA de 25 et de $50 \%$ étaient respectivement de $7-12$ et de $12-20 \mu \mathrm{g} \cdot \mathrm{ml}^{-1}$. Le propofol a un effet analogue sur les globules rouges humains in vitro $\left(R^{2}=0,98\right)$.

Conclusion : Le propofol, à des concentrations anesthésiques et subanesthésiques chez le porc, antagonise les effets d'une peroxydation forcée des globules rouges. Son mode d'action comporte l'épuration des radicaux libres provoqués par l'oxygène comme le fait le tocophérol.

From the Departments of Anaesthesia, Pharmacology and Therapeutics, ${ }^{\star}$ and Surgery, ${ }^{\dagger}$ University of British Columbia, Vancouver, British Columbia, Canada. Supported in part by a research grant from Zeneca Pharma Inc (Canada Ltd.).

Address correspondence to: Dr. David M. Ansley, Department of Anaesthesia, Room 3200, 3rd Floor, 910 West 10th Avenue, Vancouver, BC, Canada V5Z 4E3.

Presented at the 7 lst Clinical and Scientific Congress of the International Anesthesia Research Society, March 14-18,1997

San Francisco, Ca, USA.

Accepted for publication December 5, 1997. 
I NTEREST has been focused on the potential role of anaesthetics in preserving the heart and lung against ischaemia-reperfusion injury (IRI). ${ }^{1,2}$ It has been postulated that the effects of anaesthetics in this setting depend upon whether they increase or decrease oxidant-mediated cell injury. Propofol, a highly lipid soluble anaesthetic with antioxidant activity, ${ }^{3,4}$ may be a useful agent to test the hypothesis that an increase in antioxidant activity may modify or protect against cardiopulmonary IRI.

Previous studies in our laboratory have demonstrated that pretreatment with the antioxidant allopurinol can confer protection in a swine model of heart-lung transplantation which is associated with corresponding increases in the antioxidant capacity of red cells subjected to peroxide challenge ex vivo., ${ }^{5,6}$ This finding in red cells might be indicative of a generalised allopurinol-induced increase in tissue antioxidant capacity, and suggests that the antioxidant capacity of red cells may provide a convenient functional measure of drug-induced alterations in tissue antioxidant status. If such were the case, alterations in susceptibility of red cells to in vitro peroxide challenge could be useful in monitoring and optimising the effects of antioxidant agents in both experimental and clinical settings.

The aim of the present study was to investigate the antioxidant properties of propofol in swine using red cell antioxidant capacity as a functional measure of anaesthetic-induced antioxidant alterations in vivo. Our immediate interest was to determine the relationship between propofol concentration and red cell antioxidant capacity that could be applied to further clinical and experimental studies of cardiopulmonary IRI. This work included in pitro study of erythrocytes, to enhance our understanding of propofol's potential antioxidant mechanism(s) of action, at the cell membrane and intracellular level.

\section{Methods}

This study was approved by the Institutional Committee on Animal Care at the University of British Columbia. All experimental animals received humane care and treatment in compliance with established guidelines.

Nine, $20-25 \mathrm{~kg}$, fasted, female swine (sus serota domesticus) were anaesthetised with ketamine $\left(20 \mathrm{mg} \cdot \mathrm{kg}^{-1}\right)$ prior to tracheal intubation and placement of intravenous and femoral artery catheters. The lungs were ventilated to normocapnia with air/oxygen $\left(\mathrm{FiO}_{2}=0.45\right)$, and the animals were monitored with continuous electrocardiography and invasive arterial pressure. Propofol (2,6-diisopropylphenol; $\left.10 \mathrm{mg} \cdot \mathrm{ml}^{-1}\right)$ in soybean oil $\left(100 \mathrm{mg} \cdot \mathrm{ml}^{-1}\right)$, glycerol $\left(22.5 \mathrm{mg} \cdot \mathrm{ml}^{-1}\right)$, and egg lecithin (12 $\left.\mathrm{mg} \cdot \mathrm{ml}^{-1}\right)$ was administered based on the pharmacokinetic data in swine. ${ }^{7}$ Following administration of an intravenous bolus of $2.5 \mathrm{mg} \cdot \mathrm{kg}^{-1}$, propofol was infused with a Harvard pump at a rate of 36,72 and $216 \mathrm{ml} \cdot \mathrm{hr}^{-1}$ for two hour intervals in each animal to achieve target concentrations of $0-30 \mu \mathrm{g} \cdot \mathrm{ml}^{-1}$. Depth of anaesthesia was determined by the response to application of a noxious stimulus (clamp forceps applied to the forefoot knuckle) for $10 \mathrm{sec}$ at 5 , 10 and $30 \mathrm{~min}$ for each rate of infusion. Arterial blood sampling was conducted prior to propofol administration, and then at $10 \mathrm{~min}, 30 \mathrm{~min}, 60 \mathrm{~min}$, and $120 \mathrm{~min}$ for each rate of infusion, for measurement of plasma propofol concentration, plasma and RBC activities of superoxide dismutase, glutathione peroxidase, glutathione reductase, RBC catalase and RBC malondialdehyde (MDA) formation in response to oxidative challenge with t-butyl hydrogen peroxide ( $\mathrm{tBHP}$ ).

Propofol concentrations were determined using high performance liquid chromatography as reported by Plummer ${ }^{8}$ and applied by Fan et al..$^{9}$ Plasma concentrations are reported as $\mu \mathrm{M}$ and $\mu \mathrm{g} \cdot \mathrm{ml}^{-1}(25,50$ and $75 \mu \mathrm{M}$ equals $4.45,8.9$, and $13.35 \mu \mathrm{g} \cdot \mathrm{ml}^{-1}$ ) for the purpose of pharmacologic interpretation and clinical relevance. Superoxide dismutase (SOD) activity in red cells was measured using the procedure of Winterbourne et al., ${ }^{10}$ while SOD in plasma was measured utilising the method of McCord and Fridovich. ${ }^{11}$ Glutathione peroxidase (GPx) was assayed by the procedure described by Paglia and Valentine. ${ }^{12}$ Glutathione reductase (GRed) was estimated by the method of Long and Carson. ${ }^{13}$ Analysis of RBC catalase used the method of Aebi. ${ }^{14}$ The methodology for the evaluation of erythrocyte susceptibility to lipid peroxidation was as described in previous studies. ${ }^{15,16}$ Briefly, aliquots of red cells are subjected to an oxidative challenge involving incubation with t-butylhyroperoxide ( $\mathrm{tBHP}$ ) for $30 \mathrm{~min}$ at $37^{\circ} \mathrm{C}$. The reaction was terminated by the addition of an aliquot of $28 \%$ trichloroacetic acid/0.1M sodium arsenite. Following centrifugation, an aliquot of supernatant was combined with thiobarbituric acid $(0.05 \%)$ and boiled for $15 \mathrm{~min}$ to develop colour. Absorbances measured at $532 \mathrm{~nm}$ and $453 \mathrm{~nm}$ were used to estimate levels of malondialdehyde (MDA).

Malondialdehyde production and glutathione depletion (described in previous studies ${ }^{15,16}$ ) in red cells were studied in vitro using blood taken from human volunteers (ASA I; $\mathbf{n}=5$ ) and incubated with propofol $(0,12.5,25,37.5,50$ and $75 \mu \mathrm{M})$ or each component of carrier vehicle at $37^{\circ}$ Celcius. These results were compared to the data from swine following the conversion from $\mu \mathrm{g} \cdot \mathrm{ml}^{-1}$ to $\mu \mathrm{M}$ concentration.

The intrinsic antioxidant activity of propofol was compared to that of alpha-tocopherol based on the 
procedure of Martinek. ${ }^{17}$ In this assay, the antioxidant under investigation reduces ferric $\left(\mathrm{Fe}+{ }^{3}\right)$ iron to the ferrous $\left(\mathrm{Fe}^{2}\right)$ form, which in turn reacts with $2,4,6$ tripyridyl-s-triazine to produce a blue colour which is measured at $593 \mathrm{~nm}$.

The effect of propofol $(0,12.5,25,37.5,50$, and 75 $\mu \mathrm{M}$ ) on peroxide-induced oxidation of haemoglobin to methaemoglobin, an alternative mechanism of MDA production, was studied in normal haemoglobin in the presence of propofol, and haemoglobin from red cells pretreated with propofol. Exposure of haemoglobin to peroxide normally produces a colour change due to methaemoglobin formation which is quantified by measuring spectrophotometric absorbance at $630 \mathrm{~nm}$. This result is compared to the result measured following addition of test solutions incubated at $37^{\circ} \mathrm{C}$.

Data analysis included determination of mean $\pm S D$ of propofol concentrations and MDA levels prior to regression analysis by the least squares fit method, and analysis of variance. A $P<0.05$ or $\mathrm{R}^{2}>0.5$ was considered statistically significant.

\section{Results}

The first two animals were haemodynamically unstable while receiving propofol at $216 \mathrm{ml} \cdot \mathrm{hr}^{-1}$. Intravenous neosynephrine $\left(1 \mu \mathrm{g} \cdot \mathrm{kg}^{-1}\right.$, then $\left.0.25 \mu \mathrm{g} \cdot \mathrm{kg}^{-1} \cdot \mathrm{min}^{-1}\right)$ was given to maintain systolic blood pressure $>75$ $\mathrm{mmHg}$ to continue this part of the study. Following centrifugation of blood prior to assay, the supernatants of these specimens were found to be pink, indicating the presence of haemolysis at this dose of anaesthetic. In vitro studies of red cells from these samples confirmed an increased susceptibility to hypotonic lysis. Examination of our initial data in these animals indicated that increasing serum propofol concentration beyond $20-25 \mu \mathrm{g} \cdot \mathrm{ml}^{-1}$ was associated with less than a ten per cent further change (decrease) in red cell MDA levels. We therefore limited our infusion rate to 36 and $72 \mathrm{ml} \cdot \mathrm{hr}^{-1}$ in the remaining animals.

\section{Propofol concentrations in swine}

The concentrations of propofol measured during the $240 \mathrm{~min}$ administration in nine animals are shown in Figure 1. There was no response to noxious stimuli in these animals when a mean concentration of $5.57 \pm$ $2.12 \mu \mathrm{g} \cdot \mathrm{ml}^{-1}$ propofol had been achieved.

\section{Propofol antioxidant capacity in swine}

A concentration-dependant effect of propofol on production of MDA in swine red cells challenged ex vivo with $\mathrm{tBHP}(1.5 \mathrm{mM})$ was observed at sub-anaesthetic and anaesthetic concentrations (Figure 2). The relationship between MDA production and log plasma propofol concentration in swine was described by regression analysis as $\mathrm{y}=-18.683 \mathrm{x}+85.431 ; \mathrm{R}^{2}=$ 0.8174 . The effective range of propofol concentrations for a $25 \%$ reduction in MDA level was 7-12 $\mu \mathrm{g} \cdot \mathrm{ml}^{-1}$. A $50 \%$ reduction in MDA level was achieved with propofol $12-20 \mu \mathrm{g} \cdot \mathrm{ml}^{-1}$. Increasing the concen-

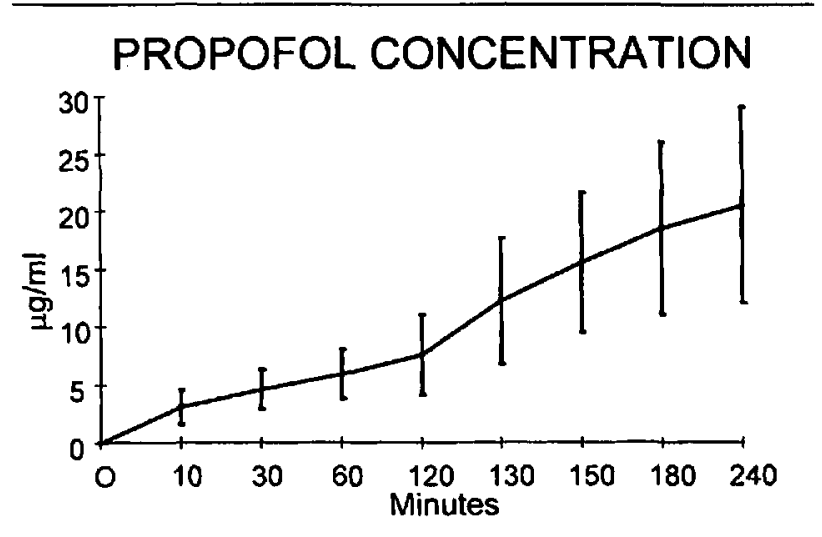

FIGURE I Plasma propofol levels in swine

Propofol administered as a bolus of $2.5 \mathrm{mg} \cdot \mathrm{kg}^{-1}$, then at 36 and $72 \mathrm{ml} \cdot \mathrm{hr}^{-1}$ for two hours at each rate, in each animal. Results beginning at concentration $=0$ are shown as mean $\pm S D, n=9$.

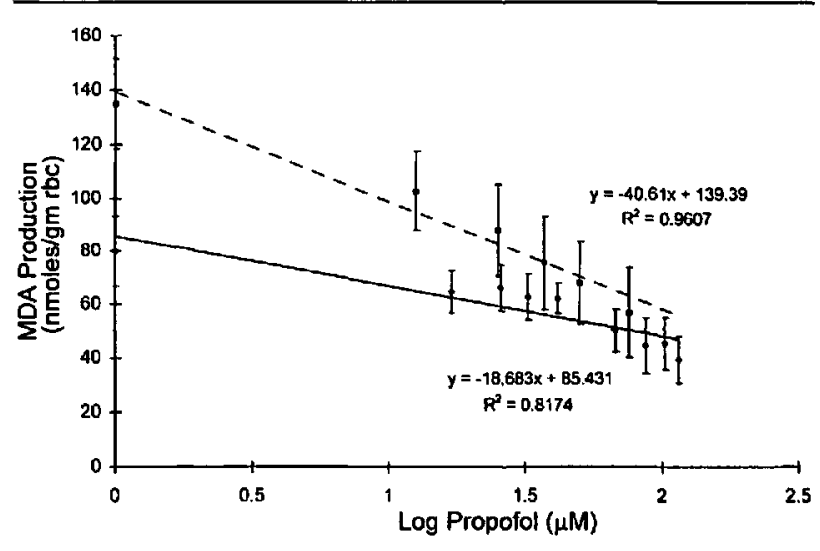

FIGURE 2 Forced peroxidation with $1.5 \mathrm{mM}$ t-BHP in swine and propofol-treated human red cells

Solid line demonstrates results of oxidative challenge of blood taken from nine swine ( $e x$ pivo) and correlated to propofol concentration at nine different intervals during propofol anaesthesia $(0$, then $2.5 \mathrm{mg} \cdot \mathrm{kg}^{-1}$ and 36 or $\left.72 \mathrm{ml} \cdot \mathrm{hr}^{-1}\right)$. Interrupted line demonstrates results of in vitro oxidative challenge of blood from five humans incubated with six concentrations of propofol $(0-100 \mu \mathrm{M})$. Results are shown as MDA production (mean \pm SD) of red cells for the nine intervals and six concentrations, respectively, each assayed in quadruplicate. 
TABLE I Oxidative enzymes in plasma and red cells from propofol-treated swine

An increase in propofol concentration produced no change in enzyme levels in plasma or red cells

\begin{tabular}{lccccccc}
\hline & \multicolumn{2}{c}{ Plasma } & & \multicolumn{2}{c}{$R B C$} \\
Propofol & $G p x$ & Gred & SOD & Catalase & GPx & GRed & SOD \\
\hline 0 & $229 \pm 44$ & $78 \pm 6$ & $5.2 \pm 0.7$ & $0.24 \pm .03$ & $37.8 \pm 7$ & $3.95 \pm 0.5$ & $1.39 \pm 0.3$ \\
$2.8 \pm 1.4$ & $228 \pm 39$ & $75 \pm 11$ & $5.1 \pm 0.8$ & $0.24 \pm .03$ & $37.8 \pm 7$ & $3.8 \pm 0.49$ & $1.41 \pm 0.3$ \\
$4.4 \pm 1.7$ & $226 \pm 41$ & $75 \pm 10$ & $5.9 \pm 1.3$ & $0.25 \pm .04$ & $38 \pm 7.2$ & $3.79 \pm 0.8$ & $1.38 \pm 0.2$ \\
$5.6 \pm 2.1$ & $231 \pm 45$ & $80 \pm 9$ & $5.4 \pm 1.1$ & $0.24 \pm .04$ & $39 \pm 7.5$ & $3.92 \pm 0.6$ & $1.30 \pm 0.5$ \\
$7.3 \pm 3.6$ & $236 \pm 42$ & $73 \pm 9$ & $4.6 \pm 0.7$ & $0.25 \pm .04$ & $37 \pm 7.9$ & $3.88 \pm 0.9$ & $1.43 \pm 0.3$ \\
$11 \pm 3.6$ & $221 \pm 41$ & $73 \pm 9$ & $5.1 \pm 0.6$ & $0.25 \pm .04$ & $39 \pm 11$ & $3.69 \pm 0.6$ & $1.40 \pm 0.3$ \\
$14 \pm 5.3$ & $223 \pm 39$ & $73 \pm 8$ & $4.7 \pm 1.1$ & $0.25 \pm .03$ & $38 \pm 8.8$ & $3.88 \pm 0.5$ & $1.39 \pm 0.2$ \\
$17 \pm 6.2$ & $223 \pm 39$ & $73 \pm 7$ & $5.1 \pm 0.9$ & $0.25 \pm .04$ & $39 \pm 8.8$ & $3.79 \pm 0.7$ & $1.38 \pm 0.3$ \\
$20 \pm 8.8$ & $217 \pm 40$ & $72 \pm 10$ & $5.2 \pm 1.5$ & $0.24 \pm .04$ & $38 \pm 9.6$ & $4.07 \pm 0.8$ & $1.41 \pm 0.3$ \\
\hline
\end{tabular}

Propofol: $\mu \mathrm{g} \cdot \mathrm{ml}^{-1} ; \mathrm{GPx}, \mathrm{GRed}=$ glutathione peroxidase, reductase: $\mathrm{nmoles} \cdot \mathrm{min}^{-1} \cdot \mathrm{ml}^{-1}(\mathrm{plasma})$;

nmoles $\cdot \mathrm{min}^{-1} \mathrm{mg}^{-1} \mathrm{Hb}$ (red cells); $\mathrm{SOD}=$ superoxide dismutase: units $\mathrm{ml}^{-1}$ (plasma); units $\cdot \mathrm{mg}^{-1} \mathrm{Hb}$ (red cells); catalase: $\mathrm{k} \cdot \mathrm{mg}^{-1} \mathrm{Hb}$

tration of propofol produced no detectable change in plasma or RBC antioxidant enzyme activities in swine (Table I).

In vitro antioxidant mechanisms in buman red cells I. Cellular: Studies of MDA production in human erythrocytes exposed to increasing concentrations of propofol in vitro confirmed the direct action of propofol on red cells (Figure 2).

II. Intracellular: Depletion of red cell glutathione (GSH), which occurs at lower concentrations of $t-B H P$ (0.025-0.100 $\mathrm{mM})$, was not detectably altered in human erythrocytes by propofol at concentrations up to $75 \mu \mathrm{M}$ in vitro (Figure 3 ). The soybean oilglycerol-lecithin vehicle had no effect on t-BHP-induced GSH depletion or MDA formation.

Propofol did not prevent the conversion of haemoglobin to methaemoglobin with concentrations up to $75 \mu \mathrm{M}$ in vitro.

In vitro biochemical comparison to tocopherol (Vitamin E) The antioxidant potential for direct scavenging of oxygen-derived free radicals by propofol is compared with that of tocopherol in Figure 4. Propofol was found to have direct antioxidant activity by a scavenging (tocopherol-like) effect. It was approximately one third as potent as alpha-tocopherol when compared on a micromolar basis with this assay system.

\section{Discussion}

The present study demonstrated that propofol, when administered in vino at anaesthetically relevant concentrations, exerts antioxidant effects, as manifested in a decreased susceptibility of red blood cells to peroxidative challenge ex vivo. This effect is similar in magnitude to that seen with the use of allopurinol, when propofol

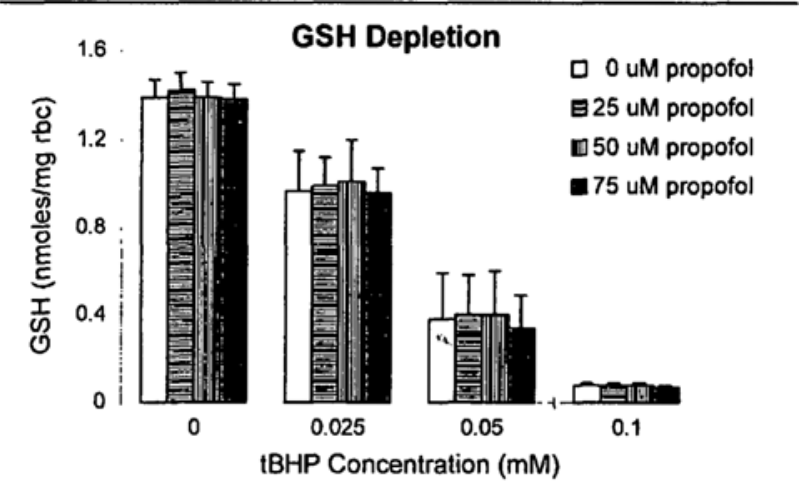

FIGURE 3 In vitro red cell susceptibility to glutathione depletion GSH levels (mean $\pm S D$ ) following red cell challenge with tBHP $(0-0.1 \mathrm{mM})$. Propofol (0-75 $\mu \mathrm{M})$ did not prevent depletion of cytosolic GSH in response to oxidative challenge. GSH levels did not differ at each concentration of tBPH despite increasing concentrations of propofol.

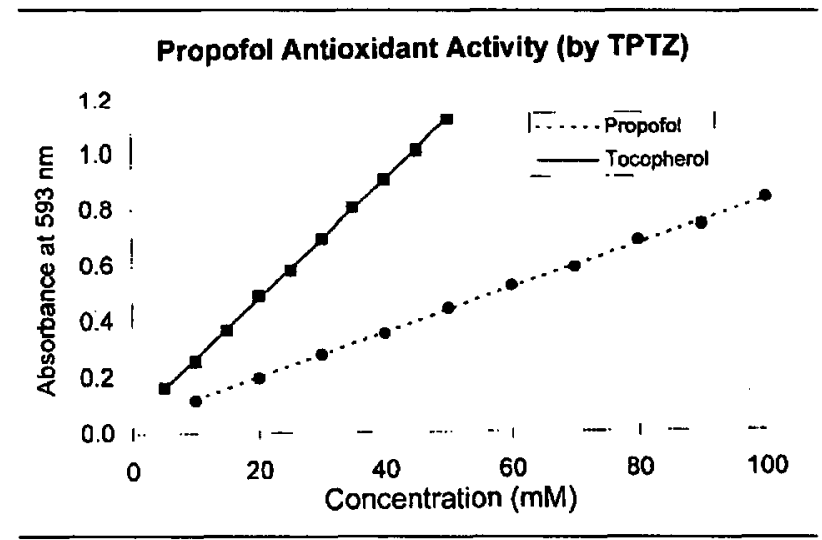

FIGURE 4 Antioxidant capacity of propofol $v s$ alpha-tocopherol TPTZ is an iron colour reagent, 2,4,6-tripyridyl-s-triazine, and an indicator of the reaction from ferric iron $\left(\mathrm{Fe}^{3+}\right)$ to ferrous iron $\left(\mathrm{Fe}^{2+}\right)$. TPTZ can be measured at near $600 \mathrm{~nm}$ under the conditions of ferrous iron. 
plasma concentration ranges from $12-20 \mu \mathrm{g} \cdot \mathrm{ml}^{-1}$. By analogy with our previous studies with allopurinol, 5,6 the effect of propofol on red cells may be indicative of alterations in the antioxidant capacity of tissues generally. Furthermore, these readily demonstrable red cell changes may provide a convenient means of assessing and optimising the effects of antioxidant interventions in pivo. The direct correlation with tissue effect will be necessary to substantiate this finding.

The antioxidant effect of propofol may have considerable clinical implications in modifying the course of ischaemia-reperfusion injury of the myocardium and other tissues. The myocardium is particularly vulnerable to oxidative injury because of the low levels of antioxidant enzymes found within this tissue. ${ }^{16,18}$ Lipid peroxidation of cell membranes is a final common pathway of tissue injury secondary to a variety of noxious stimuli. ${ }^{19}$ In contrast to the myocardium, red cells contain antioxidant enzymes in excess of the amounts necessary for them to withstand oxidantmediated injury. ${ }^{20}$ This surfeit of antioxidant capacity may also serve to protect peripheral tissues such as heart and lung against oxidative injury. ${ }^{21}$

There has been much interest in the influence of anaesthetics on the development of cardiopulmonary IRI. ${ }^{22,23}$ Anaesthetics could influence the course of IRI by effects on the production or scavenging of oxygen-derived free radicals. ${ }^{24}$ For example, halothane, enflurane, and high dose isoflurane ( $>2 \%$ end tidal) decrease the mobilisation of intracellular calcium in a dose-dependent manner. ${ }^{25}$ This reduces the activation of protein kinase $\mathrm{C}$ which has been implicated in the generation of superoxide radicals by neutrophils. Therefore, these anaesthetics could inhibit the production of superoxide radicals by their indirect effects on neutrophils. In contrast, isoflurane, in concentrations up to $2 \%$ end tidal, can enhance the production of superoxide radicals. ${ }^{25}$ Moreover, halogenated anaesthetics can be transformed into peroxyl radicals in vitro by oxidants. ${ }^{26}$ Halothane and isoflurane can also increase oxidant-mediated cell injury in vitro by increasing the production and release of eicosanoids (e.g., thromboxane and $\mathrm{PGF}_{1 \alpha}$ ). ${ }^{2}$

Recently, the intravenous anaesthetic, 2,6-diisopropylphenol, propofol, has received interest concerning its use in the setting of cardiac surgery where IRI is a risk factor for perioperative ischaemia and myocardial dysfunction. ${ }^{27,28}$ Propofol appears to act as a chain reaction-breaking antioxidant by forming a stable radical, ${ }^{29}$ and does not seem to be metabolised in mitochondria in vitro. ${ }^{29}$ The free radical scavenging properties of propofol resemble those of $\mathrm{BHT}^{30}$ and of the endogenous antioxidant, alpha-tocopherol (vitamin E). ${ }^{31}$ At concentrations of $10-30 \mu \mathrm{g} \cdot \mathrm{ml}^{-1}$, propofol preferentially scavenges organoradical species. ${ }^{4}$

Given its antioxidant potential, it seems likely that propofol could modify the extent of myocardial IRI. Functionally, enhancing red cell antioxidant capacity with propofol may serve to increase the threshold at which tissue injury would occur.

Until recently, the antioxidant potential of propofol has been studied mainly using cell and tissue culture methodologies. However, Kokita and Hara reported that propofol attenuated hydrogen peroxide-induced derangements in an isolated rat heart model. ${ }^{32}$ Although propofol ( 25 and $50 \mu \mathrm{M}$ (i.e., 4.45 and 8.9 ug. $\mathrm{ml}^{-1}$ respectively)) completely suppressed tissue production of MDA, it did not completely attenuate hydrogen peroxide-induced mechanical and metabolic alterations. In this connection, it is interesting to note that propofol exerted no demonstrable effect on the depletion of red cell GSH following exposure to $\mathrm{tBHP}$ in the concentration range of 0 to $75 \mu \mathrm{M}$ (Figure 3). This suggests that propofol may have a differential effect at the level of the cell membrane as compared to the intracellular cytosolic compartment. Alternatively, hydrogen peroxide-induced myocardial alterations may involve factors other than those directly referable to the release of unspecified mediators of injury. The exact mechanism remains to be elucidated.

Propofol's mechanism of action cannot be explained by any effect on antioxidant enzyme activities measured in this model. It has a direct effect on red cell membrane that can be demonstrated in vitro, and therefore its protective action on red cells in vivo is likely a primary effect rather than a secondary consequence of the drug's action. The stabilisation of red cells against in vitro peroxidative challenge by the other lipid soluble anaesthetics, namely the barbiturates, is associated with an inhibition of haemoglobin oxidation to methaemoglobin. ${ }^{33}$

This occurs at an intracellular level. Propofol's mechanism is different. Our data show no detectable effect on the conversion of haemoglobin to methaemoglobin in propofol-treated red cells subjected to peroxidative challenge in vitro. This confirms that propofol's antioxidant effect occurs at the level of the cell membrane.

Further studies are planned to examine the ability of propofol, at concentrations which we have shown to exert antioxidant effects, to mitigate experimental cardiopulmonary IRI and its sequelae. We are presently studying the correlation between the protective effects of propofol on human RBCs and parallel beneficial actions on cardiopulmonary function compared with those of isoflurane in the setting of cardiac surgery. This includes studies of red cell antioxidant 
capacity and pathophysiological changes in a clinical setting where propofol anaesthesia and blood cardioplegia are utilised.

In conclusion, propofol antagonises the effects of forced peroxidation of red cells at anaesthetic and subanaesthetic concentrations in swine. This appears to be direct membrane protection and not related to an effect on intracellular constituents or organelles. The mechanism of action does not involve alterations in antioxidant enzyme activities or stabilisation of heme, but its actions appear to include direct scavenging of reactive oxygen-derived free radicals in a tocopherol-like manner. Antioxidant effects in vivo were maximal at plasma concentrations of $12-20 \mu \mathrm{g} \cdot \mathrm{ml}^{-1}$ and limited additional benefit was achieved at propofol concentrations $>20-25$ $\mu \mathrm{g} \cdot \mathrm{ml}^{-1}$. Further study is necessary to establish if the antioxidant properties of propofol may prove clinically useful in reducing damage to tissues subjected to ischaemia-reperfusion.

\section{Acknowledgment}

The authors wish to acknowledge the contributions of Ms. Betty Pearson, Ms. Chris Gillespie, Ms. Joanne Sniderman, and Mr. Azim Jamani whose assistance was invaluable in the completion of this study.

\section{References}

1 Marijic J, Stowe DF, Turner LA, Kampine JP, Bosnjak $Z J$. Differential protective effects of halothane and isoflurane against hypoxic and reoxygenation injury in the isolated guinea pig heart. Anesthesiology 1990; 73 : 976-83.

2 Shayepitz JR, Johnson KJ, Knight PR. Halothane-oxidant interactions in the ex vivo perfused rabbit lung. Fluid conductance and eicosanoid production. Anesthesiology 1993; 79: 129-38.

3 Murphy PG, Myers DS, Davies MJ, Webster NR, Jones $J G$. The antioxidant potential of propofol (2,6-diisopropylphenol). Br J Anaesth 1992; 68: 613-8.

4 Green TR, Bennett SR, Nelson VM. Specificity and properties of propofol as an antioxidant free radical scavenger. Toxicol Appl Pharmacol 1994; 129: 163-9.

5 Qayumi AK, Jamieson WRE, Godin DV, et al. Response to allopurinol pretreatment in a swine model of heart-lung transplantation. J Invest Surg 1990; 3: $331-40$.

6 Qayumi AK, Godin DV, Jamieson WRE, Ko KM, Poostizadeh $A$. Correlation of red cell antioxidant status and heart-lung function in swine pretreated with allopurinol (a model of heart-lung transplantation). Transplantation 1993; 56: 37-43.

7 Coetzee A, Fourie P, Coetzee J, et al. Effect of various propofol plasma concentrations on regional myocardial contractility and left ventricular afterload. Anesth Analg 1989; 69: 473-83.

8 Plummer GF. Improved method for the determination of propofol in blood by high-performance liquid chromatography with fluorescence detection. J Chromatogr 1987; 421: 171-6.

9 Fan $S-Z, Y u H-\Upsilon$, Chen $Y-L$, Liu C-C. Propofol concentration monitoring in plasma or whole blood by gas chromatography and high-performance liquid chromatography. Anesth Analg 1995; 81 : 175-8.

10 Winterbourne $C C$, Hawkins $R E$, Brian $M$, Carrell $R W$. The estimation of red cell superoxide dismutase activity. J Lab Clin Med 1975; 85: 337-41.

11 McCord JM, Fridovich I. Superoxide dismurase. An enzymic function for erythrocuprein (hemocuprein). J Biol Chem 1969; 244: 6049-55.

12 Paglia DE, Valentine WN. Studies on the quantitative and qualitative characterization of erythrocyte glutathione peroxidase. J Lab Clin Med 1967; 77: 158-69.

13 Long $W K$, Carson PE. Increased erythrocyte glutathione reductase in diabetes mellitus. Biochem Biophys 1986; 248: 71-9.

14 Aebi $H$. Catalase. In: Bergmeyer HV (Ed.). Methods of Enzymatic Analysis. Chemie: Weinheim, 1974: 673-84.

15 Gilbert HS, Stump DD, Roth EF Jr. A method to correct for errors caused by generation of interfering compounds during erythrocyte lipid peroxidation. Anal Biochem 1984; 137: 282-6.

16 Wohaieb $S A$, Godin DV. Starvation-related alterations in free radical tissue defense mechanisms in rats. Diabetes 1987; 36: 169-73.

17 Martinek RG. Method for the determination of Vitamin E (total tocopherols) in serum. Clin Chem 1964; 10: 1078-86.

18 Burrell CJ, Blake DR. Reactive oxygen metabolites and the human myocardium. Br Heart J 1989; 61: 4-8.

19 Forman MB, Virmani R, Puett $D W$. Mechanisms and therapy of myocardial reperfusion injury. Circulation 1990; 81(Suppl): IV69-78.

20 Agar NS, Sadrzadeh SMH, Hallaway PE, Eaton JW. Erythrocyte catalase. A somatic oxidant defense? $\mathrm{J}$ Clin Invest 1986; 77: 319-21.

21 Brown JM, Grosso MA, Terada LS, et al. Erythrocytes decrease myocardial hydrogen peroxide levels and reperfusion injury. Am J Physiol 1989; 256: H584-8.

22 Warltier DC, Al-Wathiqui MH, Kampine JP, $S$ chmeling WT. Recovery of contractile function of stunned myocardium in chronically instrumented dogs is enhanced by halothane or isoflurane. Anesthesiology 1988; 69: 552-65.

23 Belo SE, Mazer CD. Effect of halothane and isoflurane on postischemic "stunned" myocardium in the dog. Anesthesiology 1990; 73: 1243-51. 
24 Tanguay $M$, Blaise $G$, Dumont $L$, Beique $G$, Hollmann $C$. Beneficial effects of volatile anesthetics on decrease in coronary flow and myocardial contractility induced by oxygen-derived free radicals in isolated rabbit hearts. J Cardiovasc Pharmacol 1991; 18 : 863-70.

25 Nakagawara M, Takeshige K, Takamatsu J, Takahashi S, Toshitake J, Minakami S. Inhibition of superoxide production and $\mathrm{Ca}^{2+}$ mobilization in human neutrophils by halothane, enflurane, and isoflurane. Anesthesiology 1986; 64: 4-12.

26 Lal M, Schöneich C, Mönig J, Asmus K-D. Rate constants for the reactions of halogenated organic radicals. Int J Radiat Biol 1988; 54: 773-85.

27 Vermeyen KM, Erpels FA, Janssen LA, Beeckman CP, Hanegreefs $G H$. Propofol-fentanyl anaesthesia for coronary bypass surgery in patients with good left ventricular function. Br J Anaesth 1987; 59: 1115-20.

28 Hall RI, Murphy JT, Moffitt EA, Landymore $R$, Pollak $P T$, Poole L. A comparison of the myocardial and metabolic and haemodynamic changes produced by propofol-sufentanil and enflurane-sufentanil anaesthesia for patients having coronary artery bypass graft surgery. Can J Anaesth 1991; 38: 996-1004.

29 Eriksson O, Pollesello P, Saris NE. Inhibition of lipid peroxidation in isolated rat liver mitochondria by the general anesthetic propofol. Biochem Pharmacol 1992; 44: 391-3.

30 Musacchio E, Rizzoli V, Bianchi M, Bindoli A, Galzigna $L$. Antioxidant action of propofol on liver microsomes, mitochondria and brain synaptosomes in the rat. Pharmacol Toxicol 1991; 69: 75-7.

31 Aarts $L$, van der Hee $R$, Dekker I, de Jong J, Langemeijer $H$, Bast $A$. The widely used anesthetic agent propofol can replace alpha-tocopherol as an antioxidant. FEBS Lett 1995; 357: 83-5.

32 Kokita $N$, Hara A. Propofol attenuates hydrogen peroxide-induced mechanical and metabolic derangements in the isolated rat heart. Anesthesiology 1996; 84: 117-27.

33 Godin DV, Mitchell MJ, Saunders BA. Studies on the interaction of barbiturates with reactive oxygen radicals: implications regarding barbiturate protection against cerebral ischaemia. Can Anaesth Soc J 1982; 29: 203-10. 